\title{
Article
}

\section{Exploratory on-line Pyrolysis and Thermally Assisted Hydrolysis and Methylation for evaluating Non- Hydrolyzable Organic Matter in Anthropogenic Soil from Central Brazilian Amazon}

\author{
Paulo S. Taube ${ }^{1 *}$, Douglas S. Silva ${ }^{1}$, Arthur A. Vasconcelos ${ }^{1}$, Lilian Rebellato ${ }^{2}$, \\ Luiz A. dos Santos Madureira ${ }^{3}$ Fabricio A. Hansel ${ }^{4}$
}

${ }^{1}$ Instituto de Biodiversidade e Florestas, Universidade Federal do Oeste do Pará, Rua Vera Paz, s/n, Santarém - PA, 68005-100, Brazil. 'Instituto de Ciências da Sociedade, Universidade Federal do Oeste do Pará,

Rua Mendonça Furtado, 2946, Santarém - PA, 68040-079, Brazil. ${ }^{3}$ Departamento de Química,

Universidade Federal de Santa Catarina, Campus Universitário Trindade, CP 476,

Florianópolis - SC, 88040-900, Brazil. ${ }^{4}$ Embrapa Florestas, Estrada da Ribeira, km 111, cx 319, Colombo - PR, 88411-000, Brazil.

\section{Graphical Abstract}

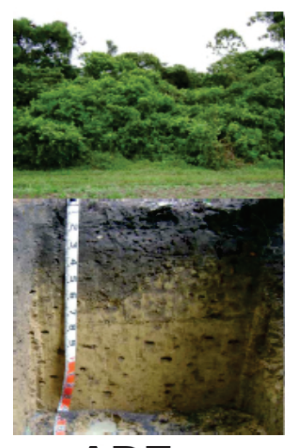

ADE

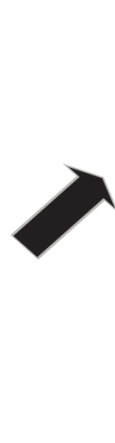

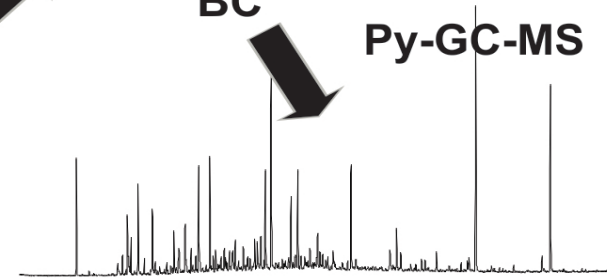
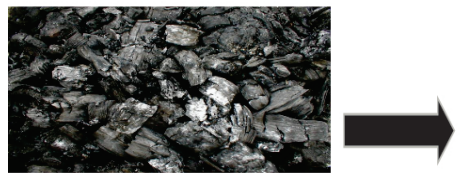

BC

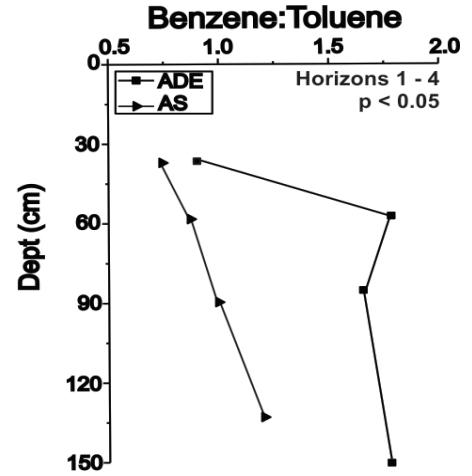

Amazonian dark earths (ADE) are characterized by high fertility and organic carbon content, the latter being associated with black carbon (BC). BC is recalcitrant in nature due to its aromatic building blocks and it is expected to remain in the non-hydrolyzable fraction after the sequential extraction of soil organic matter (SOM). In this context, the aim of this study was to compare the composition of non-hydrolyzable SOM samples from an ADE and an adjacent soil using pyrolysis - gas chromatography - mass spectrometry and thermally-assisted hydrolysis and methylation with tetramethylammonium hydroxide. We tested two hypotheses: (i) non-hydrolyzable organic matter preserves $B C$ in $A D E$ and adjacent soils; and (ii) pyrolysis products are also produced thermally and are different for ADE and adjacent soils. The results of this study showed that polycyclic aromatic hydrocarbons were the main pyrolysis products for both soils. In addition, the benzene / toluene, naphthalene / methylnaphthalene and benzofuran / methylbenzofuran ratios of the pyrolysis products observed in the case of ADE were around two times higher than the corresponding values for the adjacent soil, except in the surface horizon, which indicates the presence of a higher recalcitrant $B C$ in the ADE. The specific organic matter sources for the ADE and adjacent soil could not be differentiated.

Keywords: black carbon; charcoal; carbonization; Py-GC-MS; THM-GC-MS. 


\section{INTRODUCTION}

Anthropogenic soils called Amazonian dark earths (ADE) can be found in the Amazon region. They have surface horizons with a dark color and contain ceramic material, lithic artifacts, charcoal, fish and mammal bones, human burial remains and detritus [1]. ADE are fertile soils with high contents of $\mathrm{Ca}, \mathrm{Mg}$, $\mathrm{Zn}, \mathrm{Mn}, \mathrm{P}$ (total and available) and carbon in comparison with adjacent soils [2-9]. The dark color is related to the presence of large amounts of pyrogenic carbon, i.e., black carbon (BC) [10-11]. The high concentration of $\mathrm{BC}$ in $\mathrm{ADE}$ results from incomplete combustion of organic matter (OM) during low intensity burning [5,12], slash-and-char is another potential explanation [6,13-14].

Biochar plays a significant role in the carbon cycle and it can be used in sustainable agricultural practices [15]. This pyrogenic carbon may be modified by different processes after deposition and incorporation into soil [16]. The degradation rate of $B C$ is dependent on the temperature of the burning, intensity of carbonization, fuel source and soil conditions [17]. Laboratory incubation experiments have shown that ADE under cultivation has both rapidly mineralizable in very stable types of soil organic matter (SOM) [18]. The recalcitrance of the stable SOM is due to physical or chemical interaction with soil minerals and the intrinsic stability of the condensed aromatic structures of $\mathrm{BC}[11,18]$. The incomplete combustion of wood or other fuel material generates a wide range of products with diverse sources and recalcitrant $\mathrm{BC}$ formed anthropogenically or through natural fires can be preserved in the non-hydrolyzable fraction [19]. A previous study of extractable and hydrolysable SOM revealed some differences between anthropogenic and natural soils [9]. Pyrolysis-gas chromatography-mass spectrometry (Py-GC-MS) and thermally-assisted hydrolysis and methylation (THM-GC-MS), using tetramethylammonium hydroxide (TMAH), can provide information on the macromolecular structure of SOM, including BC [20-24]. Nevertheless, some limitations are associated with the use of Py-GC-MS for the characterization of charred OM in soils, including: (i) only a semi-quantitative response is possible [24-27]; (ii) carboxylic groups are often not detected [24-26]; (iii) aromatic compounds are formed in situ at high pyrolysis temperatures [24,28-30]; and (iv) highly condensed BC is stable under pyrolysis conditions [24,30-32]. Furthermore, THM-GC-MS can provide additional information on SOM with respect to carboxyl, hydroxyl and phenolic groups, since they are transformed into methyl esters and methyl ethers, which are more easily identified and separated by GC-MS than their underivatized counterparts [26,33-34]. In this context, the aim of this study was to evaluate the presence of $B C$ in the non-hydrolyzable SOM fraction and to compare the composition of samples of this fraction obtained from ADE and an adjacent soil using Py-GC-MS and THMGC-MS. The hypotheses considered were: (i) non-hydrolyzable SOM preserves BC in the case of ADE; and (ii) Py-GC-MS and THM-GC-MS products show differences between the ADE and the adjacent soil.

\section{MATERIALS AND METHODS Sample location}

The ADE and adjacent soil (AS) samples were collected from the Caldeirão Experimental Station

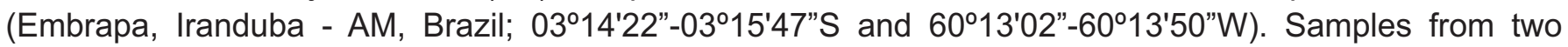
soil profiles, one ADE and one non-anthropogenic adjacent soil, were collected at four different depths for each profile. The soil with an anthropogenic horizon was classified as Pretic Anthrosol (Orthodystric, Clayic) and the non-anthropogenic soil as Haplic Xanthic Acrisol (Hyperdystric, Clayic) [35]. These soils were formed in the Tertiary period during the Alter do Chão formation. Both soils were covered by tropical rainforest. The ADE profile contained a significant quantity of archaeological pottery fragments whilst in the adjacent soil no pottery or charcoal fragments were visually observed. Other general information regarding the ADE and adjacent soil can be found in Table I. 


\section{Article}

Taube, P. S.; Silva, D. S.; Vasconcelos, A. A.; Rebellato, L.; Madureira, L. A. S.; Hansel, F. A.

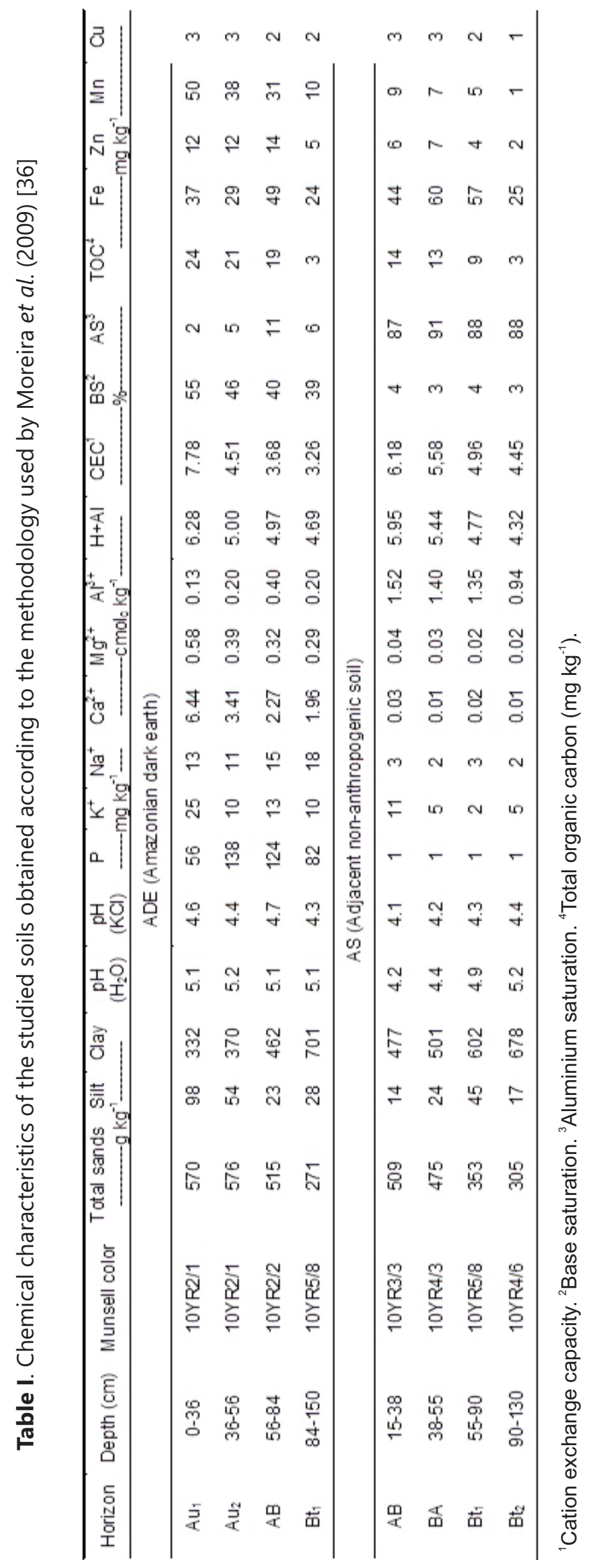




\section{Sample preparation}

The samples were dried in an oven with air circulation at $60^{\circ} \mathrm{C}$ for $24 \mathrm{~h}$. They were then macerated in a porcelain mortar and sieved $(250 \mu \mathrm{m})$. Free lipids were removed by extraction with a mixture of $\mathrm{CHCl}_{3}$ : $\left(\mathrm{CH}_{3}\right)_{2} \mathrm{CO}(9: 1 \mathrm{v} / \mathrm{v}, 10 \mathrm{~mL}$ in an ultrasound system for $30 \mathrm{~min})$ and ester-bound lipids were eliminated by alkaline hydrolysis with a $1.0 \mathrm{~mol} \mathrm{~L}{ }^{-1} \mathrm{KOH}$ solution in $\mathrm{MeOH}\left(96 \%, 10 \mathrm{~mL}, 70{ }^{\circ} \mathrm{C}, 30 \mathrm{~min}\right)$ and then extracted with $\mathrm{MeOH}: \mathrm{CHCl}_{3}(1: 1, \mathrm{v} / \mathrm{v}, 1 \times 10 \mathrm{~mL})$ and $\mathrm{CHCl}_{3}(2 \times 10 \mathrm{~mL})$. After alkaline extraction the residue was dried $\left(60^{\circ} \mathrm{C}\right)$ and crushed to obtain fine particles for the Py and THM analysis. The carbon content (\%) was measured using an elemental analyzer (Vario Macro cube, Elementar, Hanau, Germany) [37].

\section{Py-GC-MS and THM-GC-MS}

Dried soil (ca. $500 \mu \mathrm{g}$ ) was placed in a quartz tube and the tube was inserted into a Pyroprobe inlet. For the thermally-assisted hydrolysis and methylation, $5 \mu \mathrm{L}$ of TMAH $\left(0.25 \mathrm{~mol} \mathrm{~L}^{-1}\right.$ in MeOH$)$ was added and then the $\mathrm{MeOH}$ was evaporated by pre-heating the sample at $110{ }^{\circ} \mathrm{C}$ for $60 \mathrm{~s}$. Pyrolysis and $\mathrm{THM}$ were then carried out at $700{ }^{\circ} \mathrm{C}$ for $10 \mathrm{~s}$, and $600{ }^{\circ} \mathrm{C}$ for $5 \mathrm{~s}$, respectively, both with heating at $10^{\circ} \mathrm{C} / \mathrm{ms}$, using a CDS 5000 pyrolyzer (CDS analytical, Oxford, UK). The Pyroprobe interface and the oven were at a temperature of $290{ }^{\circ} \mathrm{C}$. Both the Py and THM products were analyzed on-line (inlet $290{ }^{\circ} \mathrm{C}$ with split mode 1:10) using GC-MS (Focus GC instrument coupled to a Polaris ion trap mass spectrometer; Thermo, Waltham, USA) and a DB5MS column (60 $\mathrm{m} \times 0.25 \mathrm{~mm}, 0.25 \mu \mathrm{m}$ film thickness). The GC oven programs were: (i) $40^{\circ} \mathrm{C}$ (held $5 \mathrm{~min}$ ) to $300^{\circ} \mathrm{C}$ (held $5 \mathrm{~min}$ ) at $7^{\circ} \mathrm{C} / \mathrm{min}$ for Py-GC-MS; and (ii) $40{ }^{\circ} \mathrm{C}$ (held $5 \mathrm{~min}$ ) to $150{ }^{\circ} \mathrm{C}$ at $10^{\circ} \mathrm{C} / \mathrm{min}$ and then to $300^{\circ} \mathrm{C}$ (held $5 \mathrm{~min}$ ) at $4{ }^{\circ} \mathrm{C} / \mathrm{min}$ for THM-GC-MS. Helium was used as the carrier gas at a constant flow of $1.0 \mathrm{~mL} / \mathrm{min}$. The GC-MS interface and ion source temperatures were $290{ }^{\circ} \mathrm{C}$ and $200{ }^{\circ} \mathrm{C}$, respectively. The ion trap mass spectrometer was operated in electron ionization mode at $70 \mathrm{eV}$, scanning at $\mathrm{m} / \mathrm{z} 50-650$ (0.58 total scan time), with an emission current of $250 \mathrm{~mA}$.

All compounds were identified with the support of an interactive chemical information structure (ICIS) and the NIST/EPA/NIH mass spectral database version 4.51994 , as well as from the interpretation of the mass spectra.

The relative contribution ( $R C)$ of products was quantified as the ratio between the peak area for each compound and the total area of identified peaks, according to the formula:

$$
R C_{i j}=\left(\frac{x_{i j}}{\sum x_{i}}\right) \cdot 100
$$

Where $x_{i j}$ is the total integrated area of compound "j" in sample "i", " $\sum x_{i}$ " the sum of all integrated peak areas of identified compounds and " $\mathrm{RC}_{\mathrm{ij}}$ " the relative contribution of compound "j" in sample "i".

\section{RESULTS AND DISCUSSION}

\section{General distribution of Py-GC-MS and THM-GC-MS}

The major Py-GC-MS products were monoaromatic compounds (benzene, toluene, etc.), polycyclic aromatic hydrocarbons (PAHs) (naphthalene, phenanthrene, etc.), phenols, N-compounds and polysaccharide pyrolysis products (Table II). The same compound classes were detected with THM-GCMS, but with additional information on lignin-derived products. Derivatized alkanoic and phosphoric acids were the major products observed by THM-GC-MS. Benzene was not detected with the THM-GC-MS technique, because it eluted within the solvent delay period programmed in the software. 


\section{Article}

Taube, P. S.; Silva, D. S.; Vasconcelos, A. A.; Rebellato, L.; Madureira, L. A. S.; Hansel, F. A.

Table II. Relative contribution (\%) of compounds obtained in Py-GC-MS

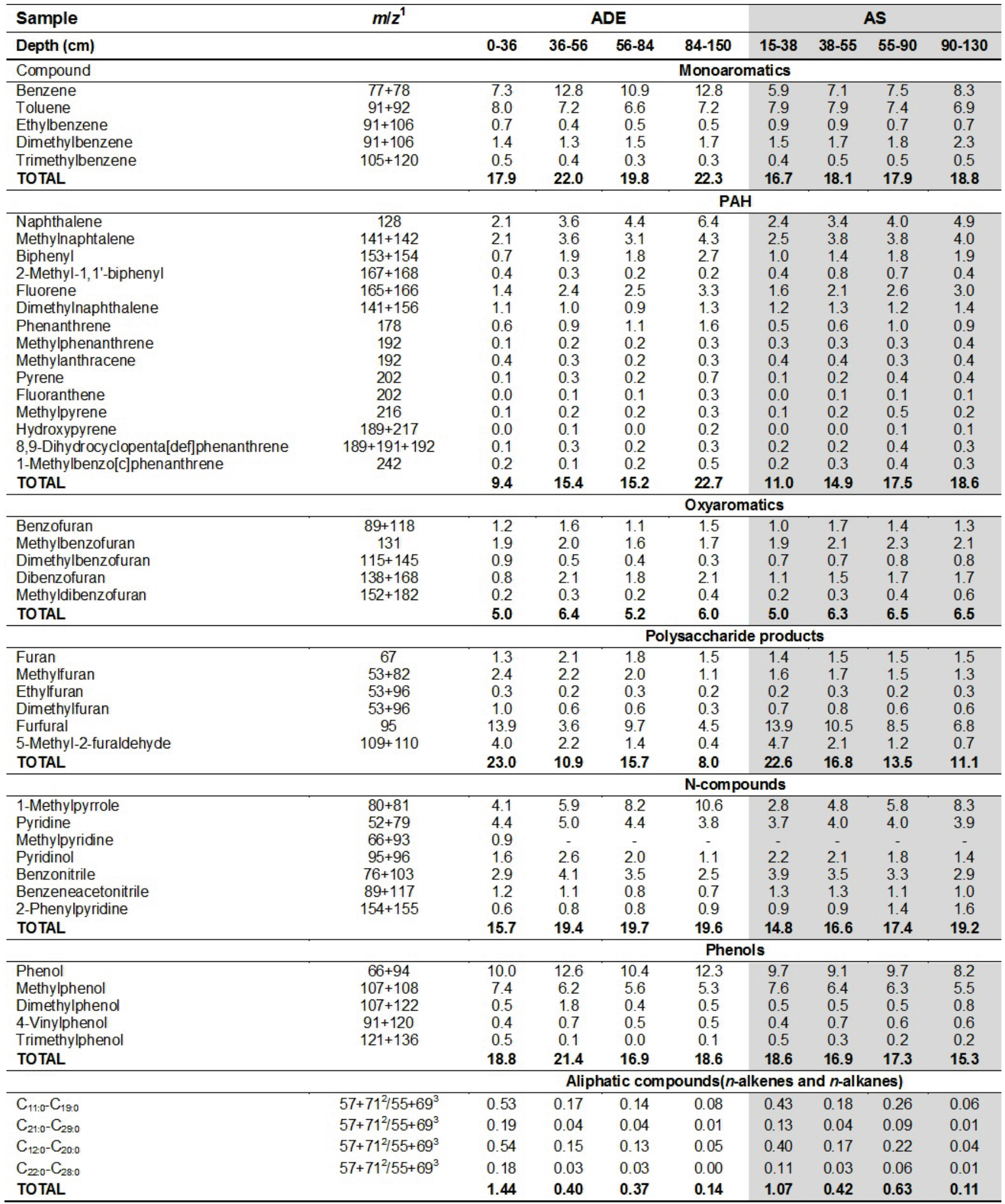

${ }^{1}$ Ion fragment used to quantify the relative contribution. ${ }^{2} n$-alkane. ${ }^{3} n$-alkene. 
In relation to the Py-GC-MS products, monoaromatic compounds (benzene, toluene, ethylbenzene, dimethylbenzene, trimethylbenzene and styrene) ranged from $16.7 \%(15-38 \mathrm{~cm})$ to $18.8 \%(90-130 \mathrm{~cm})$ in the AS soil, and from $17.9 \%(0-36 \mathrm{~cm})$ to $22.3 \%(84-150 \mathrm{~cm})$ in the ADE soil (Table II). Benzene was the main monoaromatic compound, with the exception of the top horizon of the adjacent soil, where toluene was more abundant (Table II). According to the THM-GC-MS results, the relative contribution of monoaromatic compounds in the ADE samples ranged from 3.3 to $6.3 \%$ (Table III).

Table III. Relative contribution (\%) of the compounds detected in THM-GC-MS analysis

\begin{tabular}{|c|c|c|c|c|c|c|c|c|c|}
\hline \multirow{2}{*}{$\begin{array}{l}\text { Samples } \\
\text { Depth }(\mathrm{cm})\end{array}$} & \multirow[t]{2}{*}{$m / z^{1}$} & \multicolumn{4}{|c|}{ ADE } & \multicolumn{4}{|c|}{ AS } \\
\hline & & $0-36$ & $36-56$ & $56-84$ & $84-150$ & $15-38$ & $38-55$ & $55-90$ & $90-130$ \\
\hline & & \multicolumn{8}{|c|}{ Monoaromatics } \\
\hline Toluene & $91+92$ & 0.7 & 0.8 & 4.4 & 1.3 & 2.3 & 7.3 & 4.5 & 3.0 \\
\hline Ethylbenzene & $91+106$ & 0.3 & 0.6 & 0.1 & 0.4 & 1.7 & 1.9 & 2.1 & 0.7 \\
\hline Dimethylbenzene & $91+106$ & 0.1 & 0.2 & 0.6 & 0.2 & 2.2 & 3.6 & 0.2 & 1.1 \\
\hline Styrene & $78+104$ & 0.5 & 0.7 & 0.4 & 0.6 & 0.6 & 2.3 & 0.7 & - \\
\hline Trimethylbenzene & $105+120$ & 1.7 & 1.7 & 0.9 & 1.4 & 2.5 & 0.9 & 2.3 & 0.8 \\
\hline \multirow[t]{2}{*}{ TOTAL } & & 3.3 & 4.0 & 6.3 & 4.0 & 9.2 & 15.8 & 9.8 & 5.7 \\
\hline & & \multicolumn{8}{|c|}{ Polycyclic aromatic hydrocarbons } \\
\hline Indene & $115+116$ & 0.7 & 0.4 & 0.9 & 1.1 & 2.4 & 4.4 & 1.5 & - \\
\hline Methylindene & $115+129$ & 0.4 & 0.5 & 1.0 & 0.7 & 0.8 & 2.1 & 2.0 & - \\
\hline Dimethylindene & $115+143$ & 0.6 & 0.5 & 0.3 & 0.3 & 1.3 & 1.0 & 1.0 & - \\
\hline \multirow[t]{2}{*}{ TOTAL } & & 1.7 & 1.3 & 2.2 & 2.0 & 4.5 & 7.5 & 4.6 & - \\
\hline & & \multicolumn{8}{|c|}{ Oxyaromatics } \\
\hline Benzofuran & $89+118$ & 0.3 & 0.7 & 0.1 & 1.1 & 0.7 & 0.3 & 0.4 & 0.6 \\
\hline Methylbenzofuran & 131 & 0.5 & 0.3 & 0.2 & 0.3 & 1.2 & 1.2 & 0.9 & 0.4 \\
\hline Dibenzofuran & $139+168$ & 0.3 & 0.2 & 0.2 & 0.2 & 0.3 & 0.6 & 0.4 & - \\
\hline \multirow{2}{*}{ TOTAL } & & 1.1 & 1.2 & 0.4 & 1.6 & 2.2 & 2.1 & 1.6 & 1.1 \\
\hline & & \multicolumn{8}{|c|}{ Polysaccharides } \\
\hline Dimethylfuran & $67+95$ & 0.3 & 0.3 & 0.2 & 0.3 & 0.4 & 0.1 & 0.4 & - \\
\hline Furfural & 95 & 5.5 & 9.2 & 5.3 & 8.6 & 6.2 & 5.2 & 6.7 & 1.1 \\
\hline 5-methyl-2-furaldehyde & 108 & 1.9 & 1.3 & 0.9 & 1.7 & 1.2 & 0.4 & 1.7 & 0.9 \\
\hline Trimethylfuran & $109+110$ & 1.5 & 0.9 & 1.3 & 3.6 & 2.3 & 1.6 & 5.1 & 2.8 \\
\hline \multirow[t]{2}{*}{ TOTAL } & & 9.2 & 11.7 & 7.6 & 14.2 & 10.0 & 7.3 & 13.8 & 4.8 \\
\hline & & \multicolumn{8}{|c|}{ N-compounds } \\
\hline \multirow[t]{2}{*}{ 1H-methylpyrrole } & $80+81$ & 2.4 & 3.2 & 1.5 & 9.4 & 3.0 & 2.9 & 4.4 & 7.1 \\
\hline & & & & & Methox & benze & & & \\
\hline Methoxybenzene & $78+108$ & 0.9 & 1.0 & 2.3 & 2.4 & 1.0 & 1.2 & 0.7 & 1.0 \\
\hline 1-Methoxy-4-methylbenzene & $91+122$ & 4.0 & 3.0 & 3.0 & 7.5 & 4.7 & 3.2 & 6.0 & - \\
\hline Methyl 4-methoxybenzoate & 171 & 6.1 & 3.1 & 4.5 & 2.2 & 5.9 & 3.9 & 5.5 & 7.7 \\
\hline Methyl 3-(4-methoxyphenyl)2-propenoate & $161+192$ & 0.8 & 0.1 & 0.3 & - & 0.4 & 0.3 & - & - \\
\hline 1-Methoxy-3,5-dimethylbenzene & $121+136$ & 1.7 & 7.3 & 3.6 & 7.5 & 5.6 & 2.0 & 8.3 & 1.6 \\
\hline TOTAL & & 13.6 & 14.5 & 13.7 & 19.6 & 17.6 & 10.6 & 20.5 & 10.2 \\
\hline & & & & & Dimetho & ybenz & & & \\
\hline 1.2-dimethoxybenzene & $123+138$ & 1.8 & 2.6 & 3.1 & 3.0 & 2.7 & 2.5 & 4.3 & 3.5 \\
\hline 4-methy-1,2-dimethoxybenzene & $137+152$ & 1.4 & 1.1 & 1.0 & 1.0 & 1.5 & 1.8 & 2.0 & - \\
\hline 4-vinyl-1,2-dimethoxybenzene & $149+164$ & 0.7 & 1.5 & 0.1 & - & 4.5 & 6.6 & 0.8 & - \\
\hline 4-allyl-1,2-dimethoxybenzene & $163+178$ & 0.7 & 0.5 & 0.5 & - & 1.1 & 1.1 & 0.8 & - \\
\hline Cis-1,2-dimethoxy-4-propenylbenzene & $163+178$ & 0.3 & 0.1 & 0.1 & 0.1 & 0.4 & 0.6 & 0.1 & - \\
\hline 1,2-dimethoxy-4-propenylbenzene & $163+178$ & 0.4 & 0.1 & 0.2 & - & 0.2 & 0.2 & 0.1 & - \\
\hline Methyl 3-(3,4-dimethoxyphenyl)propenoate & $191+222$ & 0.5 & 0.1 & - & - & 1.5 & 0.3 & 0.1 & - \\
\hline 1,2-Dimethylmethoxybenzene & $121+136$ & 1.7 & 7.3 & 3.6 & 7.5 & 5.6 & 2.0 & 8.3 & 1.6 \\
\hline Methyl 3-(3,4-dimethoxyphenyl)propenoate & $191+222$ & 0.7 & - & - & - & 0.4 & 0.1 & 0.3 & - \\
\hline Methyl 3,4-dimethoxybenzoate & $165+196$ & 2.0 & 0.3 & 0.2 & - & 1.8 & 0.5 & 0.4 & - \\
\hline TOTAL & & 10.2 & 13.5 & 9.0 & 11.5 & 19.7 & 15.7 & 16.9 & 5.1 \\
\hline & & & & & Trimetho & xybenz & & & \\
\hline 1,2,3-Trimethoxybenzene & $153+168$ & 2.0 & 1.7 & 1.6 & 1.1 & 2.9 & 1.4 & 2.5 & 1.6 \\
\hline 4-methy-1,2,3-trimethoxybenzene & $167+183$ & 0.3 & 0.3 & 0.3 & - & 0.4 & 0.3 & 0.4 & - \\
\hline 4-vinyl-1,2,3-trimethoxybenzene & $193+208$ & 0.2 & - & - & - & 0.2 & 0.4 & - & - \\
\hline 4-allyl-1,2,3-trimethoxybenzene & $193+208$ & 0.1 & 0.1 & - & - & 0.2 & 0.4 & 0.2 & - \\
\hline 3,4,5-Trimethoxybenzaldehyde & $181+196$ & 0.5 & 0.1 & 0.2 & - & 0.6 & 0.4 & 0.2 & - \\
\hline $1,2,3,5$-Tetramethoxybenzene* & $183+198$ & 1.4 & 0.7 & 0.4 & 0.2 & 2.0 & 1.4 & 1.2 & 0.5 \\
\hline TOTAL & & 4.5 & 2.9 & 2.4 & 1.3 & 6.1 & 4.4 & 4.5 & 2.1 \\
\hline & & & & & Dicarbc & xylic ac & & & \\
\hline Dimethyl 1,2-benzenedicarboxylate & 163 & 0.81 & 0.46 & 0.76 & 0.62 & 0.60 & 0.42 & 0.50 & 0.82 \\
\hline Trimethyl 1,2,4benzenetricarboxylate & $221+252$ & 0.19 & 0.07 & 0.13 & 0.03 & 0.20 & 0.06 & 0.03 & - \\
\hline Tetramethyl1,2,4,5-benzenetetracarboxylate & 279 & 0.08 & 0.02 & 0.08 & - & 0.07 & 0.02 & 0.01 & - \\
\hline Pentamethyl 1,2,3,4,5benzenepentacarboxylate & 368 & 0.01 & - & 0.02 & - & 0.01 & 0.01 & - & - \\
\hline Hexamethyl $1,2,3,4,5$, 6benzenehexacarboxylate & 395 & - & - & - & - & - & - & - & - \\
\hline TOTAL & & 1.09 & 0.55 & 0.99 & 0.65 & 0.88 & 0.51 & 0.54 & 0.82 \\
\hline
\end{tabular}

*Tannin derivative [60]. ${ }^{1}$ Ion fragment used to quantify the relative contribution. 


\section{Article}

Taube, P. S.; Silva, D. S.; Vasconcelos, A. A.; Rebellato, L.; Madureira, L. A. S.; Hansel, F. A.

The PAH in the samples detected by Py-GC-MS were dominated by naphthalene and its methylderivatives. The PAH values ranged from $9.4 \%(0-36 \mathrm{~cm})$ to $22.7 \%(84-150 \mathrm{~cm})$ in the ADE profile, and from $11.0 \%(15-38 \mathrm{~cm})$ to $18.6 \%(90-130 \mathrm{~cm})$ in the AS profile (Table II). Higher molecular weight PAHs, such as anthracene, phenanthrene, fluoranthene, fluorene and pyrene, were observed for both soils. The relative contribution of PAH increased with depth for both profiles, probably due to the presence of BC, since it does not degrade easily and is thus relatively resistant to decomposition (Table II). The relative distributions of oxygen-containing PAHs (e.g., benzofuran and dibenzofuran) in the two profiles were found to be similar in the Py-GC-MS analysis. In contrast, according to the THM-GC-MS results, a minor number of PAHs and oxygen-containing PAHs were detected, that is, only three compounds for each class in each of the soils (Table III).

The most abundant polysaccharide products observed by Py-GC-MS were furan, methylfuran, furfural and 5-methyl-2-furaldehyde. Their presence decreased with depth and ranged from $23.0 \%(0-36 \mathrm{~cm})$ to $8.0 \%(84-150 \mathrm{~cm})$ for ADE, and from $22.6 \%(15-38 \mathrm{~cm})$ to $11.1 \%$ for AS (Table II). In the THM-GC-MS analysis, the relative contributions of these compounds fluctuated according to depth in the ADE and AS profiles (Table III), with values ranging from $7.6 \%(56-84 \mathrm{~cm})$ to $14.2 \%(84-150 \mathrm{~cm})$ and from $4.8 \%(90-$ $130 \mathrm{~cm})$ to $13.8 \%(55-90 \mathrm{~cm})$, respectively.

The N-compounds in the Py-GC-MS products were abundant for both soils, with ranges of $15.7-19.7 \%$ in the ADE profile and $14.8-19.2 \%$ in the AS profile. Seven Py-GC-MS components were assigned, of which pyridine and benzonitrile were the most abundant. Only one $\mathrm{N}$-compound (1-H-methylpyrrole) was detected in the THM-GC-MS analysis (Tables II and III).

Phenol derivatives also contributed significantly to the Py-GC-MS pyrolyzates. Phenol, methylphenol, dimethylphenol, trimethylphenol and 4-vinylphenol were the most abundant (Table II, Figure 1A). The methylation of hydroxyl and carboxyl groups in lignin allowed a series of unambiguous lignin products to be detected with THM-GC-MS, based on 1-methoxy (from p-hydroxyphenyl, H), 1,2-dimethoxy (from guaiacyl, G) and 1,2,3-trimethoxy (from syringyl, S) moieties (Table III, Figure 1B). Of the lignin THM-GCMS-derived compounds, $\mathrm{H}$ units were the major type detected, followed by $\mathrm{G}$ and $\mathrm{S}$ units, with the exception of the $38-55 \mathrm{~cm}$ horizon in the AS profile, for which guaiacyl monomers were the most abundant (Table III). Note that the dominance of $\mathrm{H}$ over $\mathrm{G}$ and $\mathrm{S}$ moieties is consistent with the detection of 4vinyphenol using Py-GC-MS (Figure 1A). The presence of 1,2,3,4-tetramethoxybenzene also was observed in both soils (Table III). Benzene polycarboxylic acids (BPCA) were detected in the upperregions in both soils, with similar relative contributions. Dimethyl 1,2-benzenedicarboxylate (B2CA) and trimethyl 1,2,4benzenetricarboxylate (B3CA) were the most abundant BPCAs present (Table III).

Aliphatic compounds $(\mathrm{RC}<1.5 \%)$ were also detected among the Py-GC-MS products for both soils and comprised a homologous series of $n$-alkenes and $n$-alkanes ranging from $\mathrm{C}_{11}$ to $\mathrm{C}_{29}$, with a predominance of medium-chain length $\left(\mathrm{C}_{11}-\mathrm{C}_{19}\right)$ and a similar contribution of even and odd-numbered chain lengths. 

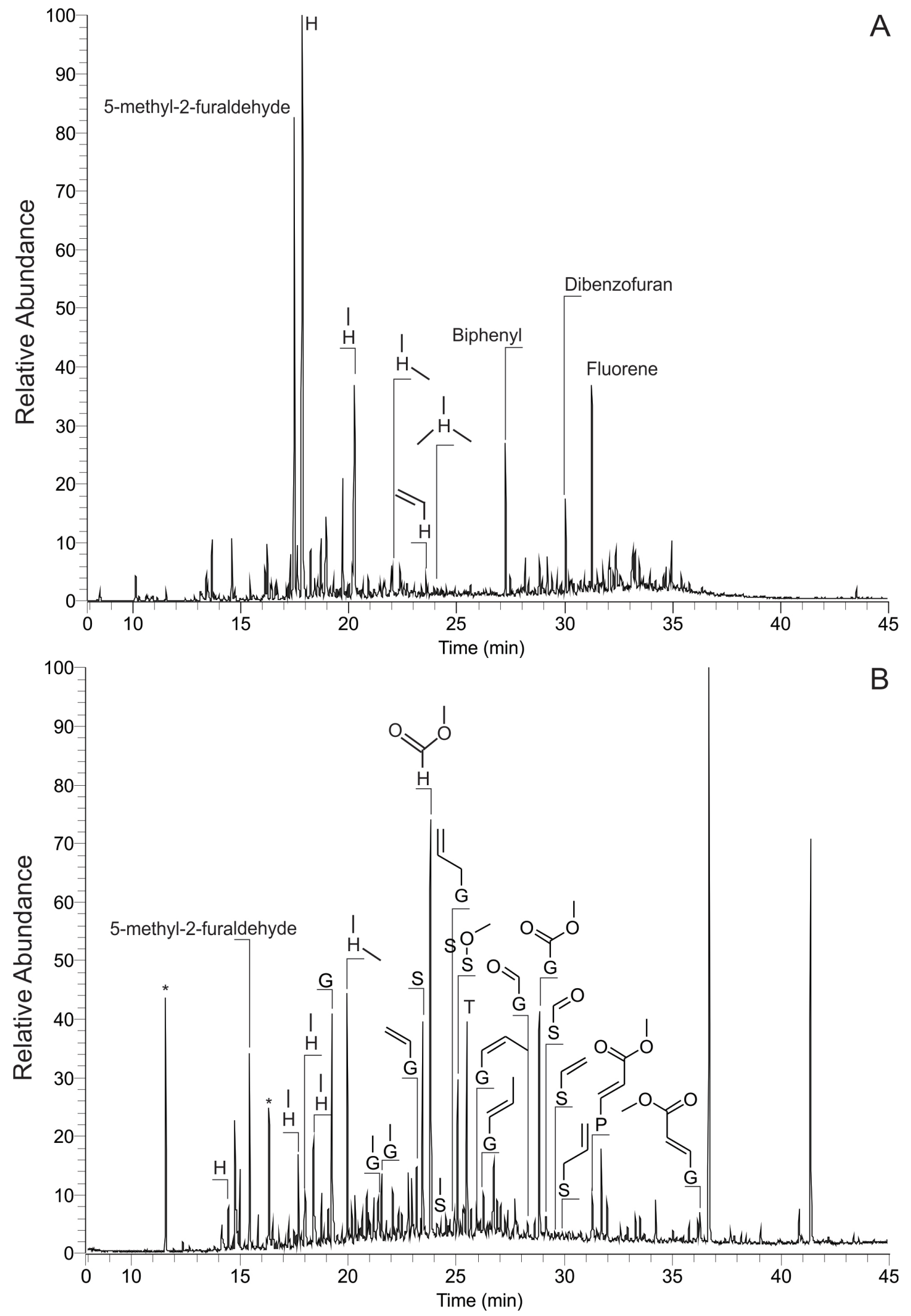

Figure 1. Partial total ion current (TIC) showing lignin-derived Py (A) and THM (B) products of non-hydrolisable SOM in top horizon of ADE. H, p-hydroxyphenyl (phenol or methoxybenzene); G, guaiacyl (guaicol or dimethoxybenzene); S, syringyl (syringol or trimethoxybenzene); T, tannin (1,2,3,4-tetramethoxybenzene), and ${ }^{*}$ contamination. 


\section{Article}

Taube, P. S.; Silva, D. S.; Vasconcelos, A. A.; Rebellato, L.; Madureira, L. A. S.; Hansel, F. A.

\section{Dealkylation ratios of pyrolysis products}

Figure 2 shows a series of ratios of pyrolysis products that reflect the difference between the ADE and adjacent samples. The ratios can be separated into three groups according to the difference in the profiles: (i) benzene/toluene and phenanthrene/methylphenanthrene ratios were higher in the ADE considering the whole profile $(p<0.05$ ); (ii) naphthalene/methylnaphthalene and benzofuran/methylbenzofuran were similar in both samples at the three lowest depths ( $p>0.05$ ); and (iii) dibenzofuran/metlhyldibenzofuran and biphenyl/methylbiphenyl were higher in the ADE in the three deepest horizons $(p<0.01$, Table II, Figure 2).
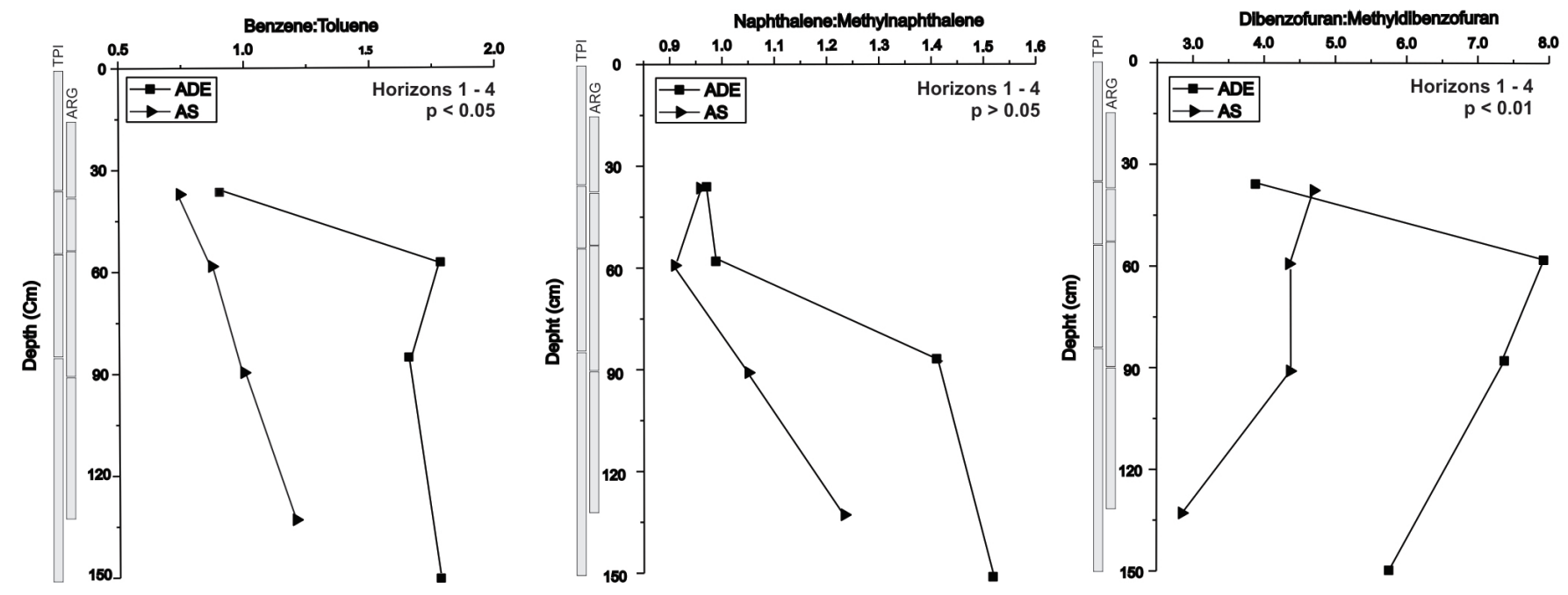

Figure. 2. Ratios of Py products for ADE and adjacent soil profiles.

\section{Characterization of non-hydrolyzable SOM}

The non-hydrolyzable SOM was marked by a similar distribution of Py-GC-MS and THM-GC-MS products for the ADE and adjacent soil profiles (Tables II and III), with only small differences in the relative abundances, which was mainly demonstrated by the dealkylation ratios of the pyrolysis product (Figure 2). The pyrolysis of SOM obtained from mineral and organic soils generally leads to a high relative contribution of PAH and benzene derivatives [24,30,38-39] of which alkyl benzenes and PAH have been attributed to the burning of biomass (BC) [24,26-27,30], methoxyphenols from lignin and carbohydrates and containing compounds from microbes [40]. In this study, benzene was a prominent component in the ADE products, mainly at lower depths $(36-150 \mathrm{~cm})$, with a lower abundance being observed for the AS profile (Table II, $\mathrm{p}<0.05$ ). In fact, the distribution and high abundance of benzene might be indicative of $\mathrm{BC}$, since this is abundant in the Py-GC-MS derived products of charcoal [23] and natural soil affected by fire [39].

It has been reported that alkylbenzenes (e.g., toluene) are pyrolysis products of microbial tissues [41], but a predominance of the pyrolysis product of peptidoglycan (i.e., acetamide), a primary component of bacteria cell walls, was not detected [42]. THM is a suitable technique for obtaining the bacterial alkanoic acid profile [43], but the amount of bacterial biomarkers (saturated branched $\mathrm{C}_{15}$ and $\mathrm{C}_{17}$ and monounsaturated $\mathrm{C}_{16}$ and $\mathrm{C}_{18}$ alkanoic acids) [44] was relatively low. However, it is possible that after the extraction of non-hydrolyzable OM most of the alkanoic acids have been removed. Thus, the alkyl benzenes (including toluene) and $\mathrm{PAH}$ detected can be assigned to $\mathrm{BC}$, and this is indicative of the presence of $B C$ in the ADE and adjacent soils. PAHs were important components of the products obtained from the soils, particularly naphthalene and its methylated counterparts, with a less significant contribution from the higher molecular weight PAHs (Table II). PAH and BPCA sources in soils are associated with the products of the incomplete combustion of $\mathrm{OM}$ (e.g. BC) incorporated through the sorption of pyrogenic products $[22,23,32,45-48]$. Some PAH results indicated that the dealkylation ratios of pyrolysis products were different when the profiles were compared, reflecting the relative accumulation of more condensed $\mathrm{BC}$ in the ADE profiles (Figure 2) [49]. In the thermochemolysis the PAHs showed the same tendency as the monoaromatic components (see above). 
As seen for the PAH components, no difference in the oxygen-containing PAHs that could differentiate the studied soils was observed (Tables II and III). Benzofuran and its counterparts are products of charred cellulose formed above $350{ }^{\circ} \mathrm{C}$ [50], and may indicate the presence of charred cellulose material in the non-hydrolyzable SOM in the two soils. Furans and anhydrosugars are typically pyrolysis products of cellulose and are commonly obtained in the Py-GC-MS of polysaccharide-rich SOM [51]. In this study, only furan-like compounds were detected in the products obtained from the non-hydrolyzable fractions of the ADE and adjacent soils (Tables II and III). The presence of levoglucosan (a product of the pyrolysis of intact polysaccharides) was not observed [50-51]. Its absence and the presence of furans in abundance may be indicative of microorganism activity, related to carbohydrate degradation in the soil, this being more pronounced with depth [52], which is in agreement with tropical soil conditions. The possibility of the presence of microbial carbohydrates cannot be totally excluded, but given the low abundance of the pyrolysis products of microbial biomarkers (e.g., acetamide) [42-44] they would be expected to be present in low amounts in the non-hydrolyzable fraction of soils. Although the Py-GC-MS technique tends to underestimate the values for $\mathrm{N}$-containing biomolecules [53-54], the $\mathrm{N}$-containing pyrolysis products from the non-hydrolyzable fraction of the two soils were abundant. The source of these compounds is related to proteins originating from plant and microbial biomass [53]. The presence of methylated pyridines and pyrroles suggests that these products may be, in part, derived from microbial biomass [55], but this is not reinforced by other biomarkers (e.g., acetamide) [42-44]. With respect to benzonitrile, its presence may be indicative of the presence of BC in the soils (Table II) [26]. A large contribution from N compounds in the pyrolysis products of SOM generally corresponds to a contribution from microbial material $[40,56-58]$. Moreover, the $\mathrm{N}$ compounds in soils are usually considered to be pyrolysis products of residues from burned non-woody material (e.g., leaves and bones) [19,59].

The presence of phenolic compounds may be indicative of a lignin component in the non-hydrolyzable SOM. It is known that lignin components are not degraded during the alkaline hydrolysis of soils [60]. The presence of 1,2,3,4-tetramethoxybenzene indicates the incorporation of tannin derivatives into soils (Table III) [61]. The presence of 4-vinylphenol may be indicative of decarboxylation of lignin during thermal decomposition [22-23,27]. The p-coumaric acid moiety is released from suberin as a primary source of 4-vinylphenol during pyrolysis, since the suberin tissue is broken down and is freely extracted with organic solvents after alkaline hydrolysis, it seems not be the source of such pyrolysis product $[9,60]$. In the THMGC-MS analysis, some additional lignin units that were not detected in the Py-GC-MS analysis appeared, such as: H, p-hydroxyphenyl (phenol or methoxybenzene); G, guaiacyl (guaicol or dimethoxybenzene); S, syringyl (syringol or trimethoxybenzene) and T, tannin (1,2,3,4-tetramethoxybenzene) (Table III, Figure 1B). The absence of these lignin derivatives during the Py-GC-MS analysis may, in part, be due to demethoxylation and dihydroxylation in the pyrolysis analysis at temperature higher than $600{ }^{\circ} \mathrm{C}[22-23,27]$. The ADE and adjacent soil profiles showed a high abundance of p-hydroxyphenyl units for all samples, with the exception of the $38-55 \mathrm{~cm}$ adjacent soil horizon, which could reflect the incorporation of an abundance of non-woody angiosperms (e.g., grasses - Poaceas and Cyperaceaes) into this horizons $[35,62]$. The presence of preserved propyl and ester groups in the side chain of the methoxybenzene and dimethoxybenzene derivatives and the absence of 1-(3,4-dimethoxyphenyl)-1,2,3-trimethoxypropane and 1-(3,4,5-trimethoxyphenyl)-1,2,3-trimethoxypropane), which indicates intact propyl site (C3) chains during THM, are not identified, implying that fresh lignin is not present in any of the samples (Table III) [63], but the relatively high abundance of $\mathrm{C}-1$ non-substituted and 1-methyl substituted compounds may indicate a mixture of degraded/charred and fresh lignin in the non-hydrolyzable SOM (Table III).

An input of cutan/suberin to the soil profiles is detected by the presence of a homologous series of alkene/alkanes (Py-GC-MS), with a major contribution in the subsoil [64]. The presence of similar contributions of even short-chain alkanes in the two soils may be a result of the "in situ" thermal degradation of biomass during the pyrolysis [65]. The presence of alkanoic acids (THM-GC-MS) could be associated with the residues surviving after the alkaline hydrolysis of plant-derived ester-bound lipids, thus corresponding to roots [64]. 


\section{Article}

Taube, P. S.; Silva, D. S.; Vasconcelos, A. A.; Rebellato, L.; Madureira, L. A. S.; Hansel, F. A.

It seems that both the ADE and adjacent soil profiles have BC in their non-hydrolyzable SOM, though it is important to note that the Py-GC-MS and THM-GC-MS data are qualitative and do not reflect the amount of $B C$ in the soils, which, in general, is greater in the ADE compared with the adjacent soil profile $[10,12]$. This possibility is reinforced by the residual carbon content (\%) after alkaline hydrolysis, which decreases with depth $(3.3,2.2,1.5$, and 0.8 for ADE and 2.3, 1.5, 1.2, and 0.7 for AS), but for the same horizon the values were always higher for the ADE. The greater contribution of $B C$ in the ADE is in agreement with the values obtained by Macedo [35], who reported amounts of charcoal of less than $2 \%$ in an adjacent soil and ranging from $5-10 \%$ in an ADE samples collected from the same site investigated in this study. Therefore, the BC formed from wildfires could be responsible for the BC signals in the AS profile. Forest fires are widespread in the Amazon region nowadays, and it can be assumed that these also occurred in the past, that is, during the ADE formation [1]. The relative increase in the PAHs with depth may indicate a high degree of relative recalcitrance in the deepest horizons of the soils [24].

In theory, adjacent soil has a non-anthropogenic and reflects the natural processes involved in SOM formation. However, the data suggest the presence of BC in the non-hydrolyzable SOM in the AS profile and its preservation in this soil fraction [24].

Special care needs to be taken when differentiating the OM residues from charred (i.e., fuel) and degraded biomass sources. In other words, it is difficult, at this stage, to identify a specific source for OM that could differentiated the ADE and adjacent soils, since it appears that many pyrolysis-derived products from the two processes (i.e., natural OM decay and charred OM) are comprised of similar compounds [20, $23,60,63,66]$. Thus, a distinction based solely on Py or THM investigations seems unable to detect which process had the greatest influence (i.e., degradation $\mathrm{x}$ charring) on the OM to yield the pyrolysis products. In this case, it is known that an anthropogenic process (e.g., the production of biochar for home gardens [68]) may be responsible for a remarkable difference in the ADE profile, and thus it was expected that a difference would be apparent when the two soil profiles were compared. The presence of BC in soils was characterized by an increase in the relative contributions of benzene, $\mathrm{PAH}$, benzofuran and benzonitrile [23-24,26-27]. Non-hydrolyzable charred OM consists mainly of highly condensed aromatic compounds regardless of the source [67]. In this context, the ADE and adjacent samples displayed practically the same products derived from Py and THM, the differences being, mainly the relative contribution of some compounds and some of the dealkylation ratios (Figure 2).

\section{$A D E B C$ features}

Kaal et al. [23] proposed the use of ratios between aromatics and their methylated counterparts to measure the charring intensity of BC. Figure 2 shows that the ADE sample has a higher benzene/toluene ratio of pyrolysis products in all horizons, and the same result was observed for phenanthrene/ methyphenanthrene $(p<0.01$, Table II, Figure 2). This trend was less evident for dibenzofuran/ metlhyldibenzofuran and biphenyl/methylbiphenyl, these ratios being higher in the ADE sample considering only the three lowest horizons ( $p<0.01$, Table II, Figure 2). This major relative contribution of aromatic compounds vs. their methylated counterparts in the ADE is a distinct feature of BC, in agreement with the greater contribution from PAHs without alkyl side chains in a TPI (Terra Preta de Índio) soil samples reported by Schellekens et al. [30] and Justi et al. [49]. These results may indicate a more recalcitrant BC with a highly condensed aromatic structure and, consequently, a higher dealkylation ratio of pyrolysis product in anthropogenic soils [26-27,49]. These differences may also be the result of different inputs and/or decomposition processes for the two soils [30].

Toluene from a microbial source may contribute to the lower value for the benzene/toluene ratio in the top horizon of the ADE, which could reflect a higher degree of microbial activity. However, considering the weak evidence of biomarkers from microbial cells in the pyrolysis products [42,44], it can be assumed that most of the toluene thermally-produced during Py-GC-MS has a BC source.

Basically, fire needs three elements for ignition: heat, fuel and an oxidizing agent $\left(\mathrm{O}_{2}\right)$. Natural fuel elements in the forest are wood and leaves, and in anthropogenic soils, besides the natural elements, other materials brought to the location from elsewhere are present (e.g., food residues). Considering the 
plausible sources for combustion in the Amazon basin (wood and leaves), the more recalcitrant BC in the ADE may be associated with the heating mode (i.e., anthropogenic fire). For example, Wolf et al. reported that plant material burns at a low median temperature (503 ${ }^{\circ} \mathrm{C}$ for shrubs) [69]. In contrast, a domestic fire using wood stacked around pottery reaches a maximum of $962^{\circ} \mathrm{C}$ [70] and a domestic fire reportedly has a median temperature of $797^{\circ} \mathrm{C}$ [69]. In this context, a more recalcitrant BC in the ADE may be due to human interference in the heating mode (e.g., slash and burn, campfire, bonfire and earth kiln).

The burning and charring of debris (e.g., bones) could take place during the clearing of an area for habitat or the production of biochar for home gardens, as currently practiced by the Caboclos people in the Amazon basin [68]. In addition, the use of bone as a fuel source associated with other fuel elements (e.g., grass and wood) in the archaeological context is well reported in the literature [71]. As the burning of this material occurs at lower temperatures and for longer periods than the burning of the wood alone, this prolonged heating could produce a more recalcitrant $B C$ in the ADE [71].

Proteinaceous biomass was detected in the Py-GC-MS but no marked difference was detected in the distribution of $\mathrm{N}$-compounds in the soils (ADE x AS, Table II). Although, the indirect presence of burned bone was suggested by Taube et al. [9], due to the high concentration of short chain $\left(<\mathrm{C}_{20}\right)$ alkanoic acids in the extracted lipids, the data reported herein does not reinforce this conclusion. However, evidence of fish bones has been observed in ADE profiles of the same region of this study, using scanning electron microscopy in combination with energy-dispersive-X-ray spectroscopy, which revealed the presence of Ca and P-derived from bones, besides if the presence of charred bones exist it could give pyrolysis products which are similar to those of any other charred proteinaceous material (e.g., leaves) [72].

\section{CONCLUSIONS}

The $B C$ present in an Amazonian dark earth (ADE) sample was produced by high-intensity fire, in contrast to the wildfires that influenced an adjacent soil sample. This afforded more recalcitrant $B C$ with a highly condensed aromatic structure in the ADE. The intense fire associated with the ADE could have occurred as a result of anthropogenic activity (e.g., slash and burn, campfire, bonfire and earth kiln).

The dealkylation ratios obtained from the Py-GC-MS analysis suggest a more condensed structure for the $B C$ in the $A D E$, which may be associated with anthropogenic fires. Thus, there is a need for future investigations using Py-GC-MS and THM-GC-MS analysis to study bone collagen alterations with respect to incomplete combustion.

\section{ACKNOWLEDGEMENTS}

The study was supported by the Brazilian CNPq (477676/2009-0) and EMBRAPA (02.09.01.014.00.00). We also thank the Universidade Federal de Santa Catarina (UFSC) and Universidade Federal do Oeste do Pará (UFOPA) for laboratory and field facilities. The authors would like to express their deepest gratitude to the unknown reviewers, without whom this work would be impossible in this format.

Manuscript received Feb. 21, 2018; revised manuscript received June 10, 2018; accepted June 15, 2018. 


\section{Article}

\section{REFERENCES}

1. Glaser, B.; Birk, J. J. Geochim. Cosmochim. Ac. 2012, 82, pp 39-51 (DOI: 10.1016/j.gca.2010.11.029).

2. Sombroek, W. G. Amazon soil: A reconnaissance of the soils of the Brazilian Amazon region. Centre for Agricultural Publications and Documentation, Wageningen, 1966.

3. Lehmann, J.; Kern, D. C.; Glaser, B.; Woods, W. I. Amazonian Dark Earths. Origin, properties and management. Kluwer Academic Publishers, Dordrecht, 2003.

4. Glaser, B.; Woods, W. Amazonian Dark Earths: Explorations in Space and Time. Springer, Berlin, 2004.

5. Glaser, B. Philos. T. Roy. Soc. B. 2007, 362, pp 187-196 (DOI: 10.1098/rstb.2006.1978).

6. Woods, W. I.; Teixeira, W. G.; Lehmann, J.; Steiner, C.; Winklerprins, A.; Rebellato, L. Amazonian Dark Earths: The First Century of Reports. In: Woods, W. I.; Teixeira, W.G.; Lehmann, J.; Steiner, C.; Winklerprins, A. M. G. A.; Rebellatto L. (Eds.). Amazonian Dark Earths: Wim Sombroeks Vision, Springer, Berlin, 2009, pp 1-14.

7. Falcão, N. P. S.; Clement, C. R.; Tsai, S. M.; Comerford, N. B. Pedology, fertility, and biology of central Amazonian Dark Earths. In: Woods, W. I.; Teixeira, W. G.; Lehmann, J.; Steiner, C.; Winklerprins, A. M. G. A.; Rebellatto, L. (Eds.). Amazonian Dark Earths: Wim Sombroeks Vision. Springer, Berlin, 2009, pp 213-228.

8. Birk, J. J.; Teixeira, W. G.; Neves, E. G.; Glaser, B. J. Archaeol. Sci. 2011, 38, pp 1209-1220 (DOI: 10.1016/j.jas.2010.12.015).

9. Taube, P. S.; Hansel, F. A.; Madureira, L. A. S.; Teixeira, W. G. Org. Geochem. 2013, 58, pp 96-106 (DOI: 10.1016/j.orggeochem.2013.02.004).

10. Glaser, B.; Balashov, E.; Haumaier, L.; Guggenberger, G.; Zech, W. Org. Geochem. 2000, 31, pp 669678 (DOI: 10.1016/S0146-6380(00)00044-9).

11. Novotny, E. H.; de Azevedo, E. R.; Bonagamba, T. J.; Cunha, T. J. F.; Madari, B. E.; Benites, V. M. Environ. Sci. Technol. 2007, 41, pp 400-405 (DOI: 10.102/es060941x).

12. Glaser, B.; Haumaier, L.; Guggenberger, G.; Zech, W. Naturwissenschaften. 2001, 88, pp 37-41 (DOI: 10.1007/s001140000193).

13. Steiner, C.; Teixeira, W. G.; Zecha, W. Slash and char: an alternative to slash and burn practiced in the Amazon Basin. In: Glaser, B.; Woods, B. W. (Eds.). Amazonian Dark Earths. Springer, Berlin and Heidelberg, 2004, pp 183-193.

14. Steiner, C. Slash and char as alternative to slash and burn: soil charcoal amendments maintain soil fertility and stablish a carbon sink. Cuvillier Verlag, Göttingen, 2007.

15. Lehmann, J.; Liang, B.; Solomon, D.; Lerotic, M.; Luizão, F.; Kinyanagi, J.; Schäfer, T.; Wirick, S.; Jacobsen, C. Global Biogeochem. Cy. 2005, 19, pp 1013-1025 (DOI: 10.1029/2004GB002435).

16. Forbes, M. S.; Raison, R. J.; Skjemstad, J. O. Sci. Total Environ. 2006, 370, pp 190-206 (DOI: 10.1016/j.scitotenv.2006.06.007).

17. Czimczik, C. I.; Masiello, C. A. Global Biogeochem. Cy. 2007, 21, GB3005 (DOI: 10.1029/2006GB002798).

18. Glaser, B.; Guggenberger, G.; Zech, W. Past anthropogenic influence on the present soil properties of anthropogenic dark earths (Terra Preta) in Amazonia (Brazil). In: Glaser, B.; Woods, B. W. (Eds). Amazonian Dark Earths. Springer, Berlin and Heidelberg, 2003, pp 227-242.

19. Knicker, H.; Totsche, K. U.; Almendros, G.; González-Vila, F. J. Org. Geochem. 2005, 36, pp 13591377 (DOI: 10.1016/j.orggeochem.2005.06.006).

20. Nierop, K. G. J.; Verstraten, J. M. Rapid. Commun. Mass Sp. 2004, 18, pp 1081-1088 (DOI: 10.1002/rcm.1449).

21. Nierop, K. G. J.; Filley, T. R. J. Anal. Appl. Pyrol. 2008, 83, pp 227-231

(DOI: 10.1016/j.jaap.2008.07.004). 
22. Kaal, J.; Rumpel, C. Org. Geochem. 2009, 40, pp 1179-1187

(DOI: 10.1016/j.orggeochem.2009.09.002).

23. Kaal, J.; Martínez-Cortizas, A.; Nierop, K. G. J. J. Anal. Appl. Pyrol. 2009, 85, pp 408-416 (DOI: 10.1016/j.jaap.2008.11.007).

24. González-Pérez, J. A.; Almendros, G.; de La Rosa, J. M.; Gozález-Vila, F. J. J. Anal. Appl. Pyrol. 2014, 109, pp 1-8 (DOI: 10.1016/j.jaap.2014.07.005).

25. Sáiz-Jiménez, C. Environ. Sci. Technol. 1994, 28, pp 1773-1780 (DOI: 10.1021/es00060a005).

26. Kaal, J.; Martínez-Cortizas, A.; Nierop, K. G. J.; Buurman, P. Appl. Geochem. 2008, 23, pp 2395-2405 (DOI: 10.1016/j.apgeochem.2008.02.026).

27. Kaal, J.; Martínez-Cortizas, A.; Buurman, P.; Boado, F. C. Quaternary Res. 2008, 69, pp 56-61 (DOI: 10.1016/j.yqres.2007.10.005).

28. Moldoveanu, S. Analytical pyrolysis of natural organic polymers. In: Techniques and Instrumentation in Analytical Chemistry, v. 20, Elsevier, Amsterdam, 1998.

29. Kaal, J.; Brodowski, S.; Baldock, J. A.; Nierop, K. G. J.; Cortizas, A. M. Org. Geochem. 2008, 39, pp 1415-1426 (DOI: 10.1016/j.orggeochem.2008.06.011).

30. Schellekens, J.; Almeida-Santos, T.; Macedo, R. S.; Buurman, P.; Kuyper, T. W.; Vidal-Torrado, P. Geoderma. 2017, 288, pp 154-165 (DOI: 10.1016/j.geoderma.2016.11.001).

31. Poirier, N.; Derenne, S.; Balesdent, J.; Mariotti, A.; Massiot, D.; Largeau, C. Eur. J. Soil Sci. 2003, 54, pp 243-255 (DOI: 10.1046/j.1365-2389.2003.00520.x).

32. Rumpel, C.; González-Pérez, J. A.; Bardoux, G.; Largeau, C.; Gonzalez-Vila, F. J.; Valentin C. Org. Geochem. 2007, 38, pp 911-920 (DOI: 10.1016/j.orggeochem.2006.12.014).

33. Garcette-Lepecq, A.; Derenne, S.; Largeau, C.; Bouloubassi, I.; Saliot, A. J. Anal. Appl. Pyrol. 2001, 61, pp 147-164 (DOI: 10.1016/S0165-2370(01)00133-4).

34. Shadkami, F.; Helleur, R. J. Anal. Appl. Pyrol. 2010, 89, pp 2-16 (DOI: 10.1016/j.jaap.2010.05.007).

35. Macedo, R. S. Pedogênese e indicadores pedoarqueológicos em Terra Preta de Índio no município de Iranduba - AM. Doctoral thesis, 2014, Escola Superior de Agricultura Luiz de Queiroz, University of São Paulo, Piracicaba, Brazil.

36. Moreira, A.; Teixeira, W. G.; Martins, G. C.; Falcão, N. P. S. Métodos de caracterização química de amostras de horizontes antrópicos das Terras Pretas de Índio. In: Teixeira, W. G.; Kern, D. C.; Madari, B. E.; Lima, H. N.; Woods, W. (Eds). As Terras Pretas de Índio: sua caracterização e uso deste conhecimento na criação de novas áreas. Embrapa Amazônia Ocidental, Manaus, 2009, pp 201-211.

37. Silva-Oliveira, D. M.; Lima, R. P.; Barretom, M. S. C.; Verburg, E. E. J.; Mayrink, G. C. V. J. Soils Sediments, 2016, 176, pp 1-10 (DOI: 10.1007/s11368-016-1474-6).

38. Schellekens, J.; Barberá, G. G.; Buurman, P.; Pérez-Jordà, G.; Martínez-Cortizas, A. J. Anal. Appl. Pyrol. 2013, 104, pp 287-298 (DOI: 10.1016/j.geoderma.2016.11.001).

39. Marques, F. A.; Buurman, P.; Schellenkens, J.; Vidal-Torrado, P. J. Anal. Appl. Pyrol. 2015, 113, pp 518-528 (DOI: 10.1016/j.jaap.2015.03.016).

40. Vancampenhout, K.; Schellekens, J.; Slaets, J.; Hatté, C.; Buurman, P. Quatern. Int. 2016, 418, pp 105-115 (DOI: 10.1016/j.quaint.2015.11.057).

41. Simmonds, P. G. Appl. Microbiol. 1970, 20, pp 567-527.

42. Eudy, L.W.; Walla, M.D.; Hudson, J.R.; Morgan, S.L.; Fox, A. J. Anal. Appl. Pyrol. 1985, 7, pp 231-247 (DOI: 10.1016/0165-2370(85)80112-1).

43. Dworzanski, J. P.; Berwald, L.; McClennen, W. H.; Meuzelaar, H. L. C. J. Anal. Appl. Pyrol. 1991, 21, pp 221-232 (DOI: 10.1016/0165-2370(91)80027-6).

44. Goossens, H.; Irene, W.; Rijpstra, C.; Düren, R. R.; de Leeuw, J. W.; Schenck, P. A. Adv. Org. Geochem. 1986, 10, pp 683-696 (DOI: 10.1016/S0146-6380(86)80004-3). 


\section{Article}

Taube, P. S.; Silva, D. S.; Vasconcelos, A. A.; Rebellato, L.; Madureira, L. A. S.; Hansel, F. A.

45. Glaser, B.; Haumaier, L.; Guggenberger, G.; Zech, W. Org. Geochem. 1998, 29, pp 811-819 (DOI: 10.1016/S0146-6380(98)00194-6).

46. González-Vila, F. J.; Tinoco, P.; Almendros, G.; Martín, F. J. Agr. Food Chem. 2001, 49, pp 1128-1131 (DOI: 10.1021/jf0006325).

47. Almendros, G.; Knicker, H.; González-Vila, F. J. Org. Geochem. 2003, 34, pp 1559-1568 (DOI: 10.1016/S0146-6380(03)00152-9).

48. Naafs, D. F. W.; van Bergen, P. F.; Boogert, S. J.; de Leeuw, J. W. Soil Biol. Biochem. 2004, 36, pp 297-308 (DOI: 10.1016/j.soilbio.2003.10.005).

49. Justi, M.; Schellekens, J.; Camargo, P. B.; Vidal-Torrado P. Org. Geochem. 2017, 113, pp 196-209 (DOI: 10.1016/j.orggeochem.2017.06.002).

50. Pastorova, I.; Botto, R. E.; Arisz, P. W.; Bonn, J. J. Carbohyd. Res. 1994, 262, pp 27-47 (DOI: 10.1016/0008-6215(94)84003-2).

51. Poirier, N.; Sohi, S. P.; Gaunt, J. L.; Mahieu, N.; Randall, E. W.; Powlson, D. S.; Evershed, R. P. Org. Geochem. 2005, 36, pp 1174-1189 (DOI: 10.1016/j.orggeochem.2005.03.005).

52. van Bergen, P. F.; Bull, I. D.; Poulton, P. R.; Evershed, R. P. Org. Geochem. 1997, 26, pp 117-135 (DOI: 10.1016/S0146-6380(96)00134-9).

53. Chiavari, G.; Galletti, G. C. J. Anal. Appl. Pyrol. 1992, 24, pp 123-137 (DOI: 10.1016/0165-2370(92) 85024-F).

54. Kaal, J.; Baldock, J. A.; Buurman, P.; Nierop, K. G. J.; Pontevedra-Pombal, X.; Martínez-Cortizas, A. Org. Geochem. 2007, 38, pp 1097-1111 (DOI: 10.1016/j.orggeochem.2007.02.008).

55. Chefetz, B.; Tarchitzky, J.; Deshmukh, A. P.; Hatcher, P. G.; Chen, Y. Soil Sci. Soc. Am J. 2002, 66, pp 129-141.

56. Buurman, P.; Peterse, F.; Almendros, M. G. Eur. J. Soil Sci. 2007, 58, pp 1330-1347 (DOI: 10.1111/j.1365-2389.2007.00925.x).

57. Buurman, P.; Schellekens, J.; Fritze, H.; Nierop, K. G. J. Soil Biol. Biochem. 2007, 39, pp 607-621 (DOI: 10.106/j.soilbio.2006.09.012).

58. Derenne, S.; Quénéa, K. J. Anal. Appl. Pyrol. 2015, 111, pp 108-120 (DOI: 10.1016/j.jaap.2014.12.001).

59. Adamiano, A.; Fabbri, D.; Falini, G.; Belcastro, M. J. Anal. Appl. Pyrol. 2013, 100, pp 173-180 (DOI: 10.1016/j.jaap.2012.12.014).

60. Nierop, K. G. J.; Naafs, D. F. W.; Verstaten, J. M. Org. Geochem. 2003, 34, pp 719-729 (DOI: 10.1016/S0146-6380(03)00042-1).

61. Page, D. W.; van Leeuwen, J. A.; Spark, K. M.; Mulcahy, D. E. J. Anal. Appl. Pyrol. 2002, 65, pp 269285 (DOI: 10.1016/S0165-2370(02)00005-0).

62. Kristense, R.; Coulson, S.; Gordon, A. J. Anal. Appl. Pyrol. 2009, 86, pp 90-98 (DOI: 10.1016/j.jaap.2009.04.009).

63. Mckinney, D. E.; Carson, D. M.; Clifford, D. J.; Minard, R. D.; Hatcher, P. G. J. Anal. Appl. Pyrol. 1995, 34, pp 41-46 (DOI: 10.1016/0165-2370(94)00865-X).

64. Nierop, K. G. J. Org. Geochem. 1998, 29, pp 1009-1016 (DOI: 10.1016/S0146-6380(98)00165-X).

65. Eckmeier, E.; Wiesenberg, G. L. B. J. Archael. Sci. 2009, 36, pp 1590-1596 (DOI: 10.1016/j.jas.2009.03.021).

66. Sáiz-Jiménez, C.; de Leeuw, J. W. Org. Geochem. 1984, 6, pp 417-422 (DOI: 10.1016/0146-6380(84)90064-0).

67. Knicker, H. Biogeochemistry. 2007, 85, pp 91-118 (DOI: 10.1007/s10533-007-9104-4). 
68. Winklerprins, A. M. G. A. 2009. Sweep and char a creation of Amazonian dark earths in homegardens. In: Woods, W. I.; Teixeira, W. G.; Lehmann, J.; Steiner, C.; Winklerprins, A. M.G. A.; Rebellatto, L. (Eds.). Amazonian Dark Earths: Wim Sombroeks Vision. Springer, Berlin, 2009, pp 205-211.

69. Wolf, M.; Lehndorff, E.; Wiesenberg, G. L. B.; Stockhausen, M.; Schwark, L.; Amelung, W. Org. Geochem. 2013, 55, pp 11-21 (DOI: 10.1016/j.orggeochem.2012.11.002).

70. Shipman, P.; Foster, G.; Schoeninger, M. J. Archaeol. Sci. 1984, 11, pp 307-325 (DOI: 10.1016/0305-4403(84)90013-X).

71. Théry-Parisot, I. J. Archaeol. Sci. 2002, 29, pp 1415-1421 (DOI: 10.1006/jasc.2001.0781).

72. Schaefer, C. E. G. R.; Lima, H. N.; Gilkes, R. J.; Mello, J. W. V. Aust. J. Soil Res. 2004, 42, pp 401409 (DOI: 10.1071/SR03106). 